American Journal of Environmental Sciences 3 (2): 60-66, 2007

ISSN 1553-345X

(C) 2007 Science Publications

\title{
Removal and Recovery of Uranium using Microorganisms Isolated from North American Uranium Deposits
}

\author{
Takehiko Tsuruta \\ Department of Applied Chemistry, Tohwa University, Fukuoka 815-8510, Japan
}

\begin{abstract}
Some attempts were made to remove and recover uranium that may be present in nuclear fuel effluents and mine tailings using microorganisms isolated from North American uranium deposits. To establish which microorganisms accumulate the most uranium, hundreds strains of microorganisms were screened. Of these strains of microorganisms tested, extremely high uranium accumulating ability was found in some bacteria isolated from North American uranium deposits. These bacterial strains, such as Arthrobacter and Bacillus sp., can accumulate about $2500 \mu \mathrm{mol}$ uranium per gram dry wt. of microbial cells within one hour. These microbial cells can remove uranium from the uranium refining waste water with high efficiency. These microbial cells can also accumulate thorium as well as uranium with high efficiency. The microbial cells immobilized with polyacrylamide gel have excellent handling characteristics and can be used repeatedly in the adsorption-desorption cycles. These new microorganisms isolated from uranium deposits can be used as an adsorbing agent for the removal of the nuclear fuel elements, which may be present in nuclear fuel effluents, mine tailings and other waste sources.
\end{abstract}

Key words: Arthrobacter, Bacillus, microorganism, removal and recovery of uranium, thorium

\section{INTRODUCTION}

The recoveries of nuclear fuel elements, such as uranium and thorium, from aqueous systems have become the center of wide interest of exploit undeveloped energy resources. The removal of radioactive elements and toxic heavy metals from contaminated sources also seems to be a worthwhile subject to investigate in terms of environmental control. In this regard, efforts have especially concentrated on studying accumulation of the uranium by microorganisms, including bacteria ${ }^{[1-7]}$, fung $i^{[2,8-11]}$ and yeasts $^{[7,2]}$.

We have investigated uranium accumulation from aqueous systems using microorganisms isolated from uranium mines, among which some strains of bacteria were found to possess extremely high uranium accumulating ability ${ }^{[13]}$. Microbial biomass may thus be considered for use as an adsorbing agent for the recovery and removal of uranium that may be present in metallurgical effluents, mine tailings and other waste sources.

In uranium deposits, it can be presumed that some microorganisms having a high accumulating ability for uranium and different species of microorganisms having an ability to leach uranium from ore may exist in mine soil and aqueous systems. It would, therefore, be useful to find further microorganisms having an enhanced ability to accumulate uranium from uranium mines.

Recently, we screened hundreds of microorganisms existing in uranium deposits for their ability to accumulate large amount of uranium, and found some new strains which accumulated large amount of uranium, such as Bacillus subtilis in Australlia and Arthrobacter and Bacillus sp. in North America ${ }^{[14]}$. The accumulation using Bacillus subtilis in Australlia was reported in detail, however, uranium accumulation using Arthrobacter and Bacillus sp. was not reported in detail. In this study, I discuss whether new strains of microorganisms found in North American uranium deposits, especially Arthrobacter sp., can be used for the removal of nuclear fuel elements such as uranium from uranium refining wastewater.

\section{MATERIALS AND METHODS}

Culture of microorganisms: The medium for growing microorganisms contained $3 \mathrm{~g} \mathrm{~L}^{-1}$ meat extract, $5 \mathrm{~g} \mathrm{~L}^{-1}$ peptone and $5 \mathrm{~g} \mathrm{~L}^{-1} \mathrm{NaCl}$ in deionized water. The microorganisms were maintained on agar slants and grown in $300 \mathrm{~mL}$ of the medium in a $500 \mathrm{~mL}$ flask with continuous shaking $(120 \mathrm{rpm})$ for $72 \mathrm{~h}$ at $30^{\circ} \mathrm{C}$. Cells were collected by centrifugation, washed thoroughly with deionized water and then used in the following accumulation experiments.

Screening of microorganisms for their ability to accumulate uranium: Uranium was supplied by $\mathrm{UO}_{2}\left(\mathrm{NO}_{3}\right)_{2}$. The $\mathrm{pH}$ of the solution was adjusted at 5.8 with $0.1 \mathrm{M} \mathrm{HNO}_{3}$. Resting microorganisms (15 mg dry wt. basis) were suspended in $100 \mathrm{~mL}$ solution ( $\mathrm{pH}$ 5.8) containing $84 \mu \mathrm{M}$ uranium and the suspension was shaken for $1 \mathrm{~h}$ at room temperature. The microorganisms were then collected by filtration through a membrane filter (pore size $0.2 \mu \mathrm{m}$ ). The amounts of accumulated uranium by the cells were determined by measuring uranium in the filtrate using an inductively coupled plasma quantometer (ICPS8000, Shimadzu Corporation, Kyoto, Japan).

\footnotetext{
Corresponding Author:

Takehiko Tsuruta, Department of Applied Chemistry, Tohwa University, 1-1-1 Chikushigaoka, Fukuoka 815-8510, Japan, Tel: +81-92-541-1512, Fax: +81-92-552-2707
} 
Effect of $\mathrm{pH}$ on the uranium accumulation: The $\mathrm{pH}$ of the solution was adjusted to the desired value with $0.1 \mathrm{M}$ $\mathrm{HNO}_{3}$ or $0.1 \mathrm{M} \mathrm{NaOH}$. Resting Arthrobacter cells (15 $\mathrm{mg}$ dry wt. basis) were suspended in $100 \mathrm{~mL}$ solution containing $84 \mu \mathrm{M}$ uranium for $1 \mathrm{~h}$ at room temperature.

Effect of external uranium concentration on the uranium accumulation: Resting Arthrobacter cells (15 mg dry wt. basis) were suspended in $200 \mathrm{~mL}$ solution (pH 5.8) containing a desired amount of uranium for $1 \mathrm{~h}$ at room temperature.

Time course of the uranium accumulation: Resting Arthrobacter cells (15 mg dry wt. basis) were suspended in $100 \mathrm{~mL}$ solution ( $\mathrm{pH} 5.8)$ containing $84 \mu \mathrm{M}$ uranium at room temperature.

Washing of microbial cells with EDTA solution: Resting cells (15 mg dry wt. basis) were suspended in $100 \mathrm{~mL}$ solution ( $\mathrm{pH} \mathrm{6.0)}$ containing $84 \mu \mathrm{M}$ uranium for $1 \mathrm{~h}$ at room temperature. Microbial cells with accumulated uranium were washed three times with 10 $\mathrm{mL}$ of $10 \mathrm{mM}$ EDTA solution.

Distribution of the Arthrobacter cells: Resting cells (640 mg fresh weight) were suspended in $1000 \mathrm{~mL}$ solution ( $\mathrm{pH} 5.8$ ) containing $500 \mu \mathrm{M}$ of uranium for $1 \mathrm{~h}$ at room temperature. The Arthrobacter cells having accumulated heavy metal ions were fractionated as described in Fig. 1. The freeze-dried Arthrobacter cells, cell wall and intracellular particle fractions were digested in $\mathrm{HNO}_{3} / \mathrm{H}_{2} \mathrm{SO}_{4}$ solution.

Selective accumulation of uranium using Arthrobacter., US-10 cells: Resting cells (15 mg dry wt. basis) were suspended in $100 \mathrm{~mL}$ of a solution ( $\mathrm{pH} 5.0)$ containing $4 \times 10^{-5} \mathrm{M} \mathrm{Mn}^{2+}, \mathrm{Co}^{2+}, \mathrm{Ni}^{2+}, \mathrm{Cu}^{2+}, \mathrm{Zn}^{2+}, \mathrm{Cd}^{2+}$ and $\mathrm{UO}_{2}{ }^{2+}$ for $1 \mathrm{~h}$ at room temperature.

Accumulation of thorium and selective accumulation of thorium and uranium: Thorium was supplied by $\mathrm{Th}\left(\mathrm{NO}_{3}\right)_{4}$. Resting cells of Arthrobacter cells (15 mg dry wt. basis) were suspended in $100 \mathrm{~mL}$ solution $(\mathrm{pH} 3.5)$ containing $50 \mu \mathrm{M}$ thorium and/or uranium for $1 \mathrm{~h}$ at room temperature.

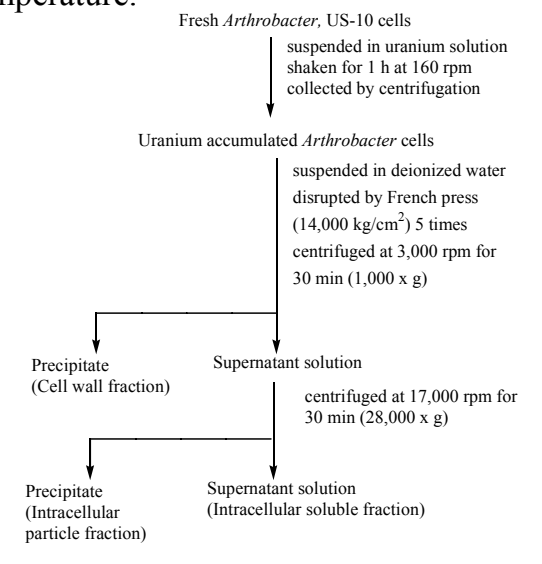

Fig. 1: Fractionation of Arthrobacter, US-10 cells. Accumulation condition was shown in Table 2
Immobilization of microbial cells: Five grams of precultured Arthrobacter cells were suspended in $4.5 \mathrm{~mL}$ isotonic sodium chloride solution and $680 \mathrm{mg}$ acrylamide monomer, $34 \quad \mathrm{mg} \quad \mathrm{N}$, N'-methylene-bis(acrylamide), $\quad 0.3 \quad \mathrm{~mL}$ 3-dimethylaminopropionitrile solution (5\%) and 0.34 $\mathrm{mL}$ potassium persulfate solution $(2.5 \%)$ were added to the suspension. After solidification, the gel was crushed into small pieces (50-100 mesh), washed thoroughly with isotonic sodium chloride solution followed by deionized water and then used for adsorption experiments.

Recovery of uranium by immobilized microorganisms: Fifteen milliliters of a solution $(\mathrm{pH}$ 5.8) containing $42 \mu \mathrm{M}$ uranium was adsorbed on a column (bed volume, $2 \mathrm{~mL}$ ) of immobilized Arthrobacter cells at a space velocity of $20 \mathrm{~h}^{-1}$. Adsorbed uranium was desorbed with $10 \mathrm{~mL}$ of $0.1 \mathrm{M} \mathrm{Na}_{2} \mathrm{CO}_{3}$ solution. The repetition test was carried out five times.

Removal of uranium from uranium refining waste water by microorganisms: Uranium refining waste water $(200 \mathrm{~mL}, \mathrm{pH} 5)$ supplemented with $2.1 \mathrm{mM}$ of uranium were adsorbed on a column (bed volume 2 $\mathrm{mL}$ ) of immobilized microbial cells at Space velocity of $10 / \mathrm{h}$ at room temperature.

\section{RESULTS}

Screening of microorganisms isolated from North American uranium deposits for their ability to accumulate uranium: To determine the ability of

Table 1: Accumulation of uranium using microorganisms isolated

\begin{tabular}{llll}
\multicolumn{4}{c}{ from soils or water from uranium mine } \\
\hline Strain & U accumulated & Strain & U accumulated \\
Number & $(\%)$ & Number & $(\%)$ \\
\hline US-1 & 14.0 & CAN-1 & 12.6 \\
US-2 & 17.1 & CAN-2 & 23.7 \\
US-3 & 23.9 & CAN-3 & 33.9 \\
US-4 & 38.7 & CAN-4 & 49.8 \\
US-5 & 43.9 & CAN-5 & 55.7 \\
US-6 & \multicolumn{2}{c}{58.9} & CAN-6 \\
US-7 & 72.0 & CAN-7 & 74.2 \\
US-8 & 84.4 & CAN-8 & 85.7 \\
Bacillus sp., US-9 & 95.9 & CAN-9 & 95.4 \\
Arthrobacter sp., US-10 & 96.4 & CAN-10 & 96.9 \\
\hline
\end{tabular}

Resting cells (15.0 mg dry weight basis) were suspended in $100 \mathrm{~mL}$ (pH 6) solution containing $84 \mu \mathrm{M}$ of uranium for $1 \mathrm{~h}$ at room temperature 


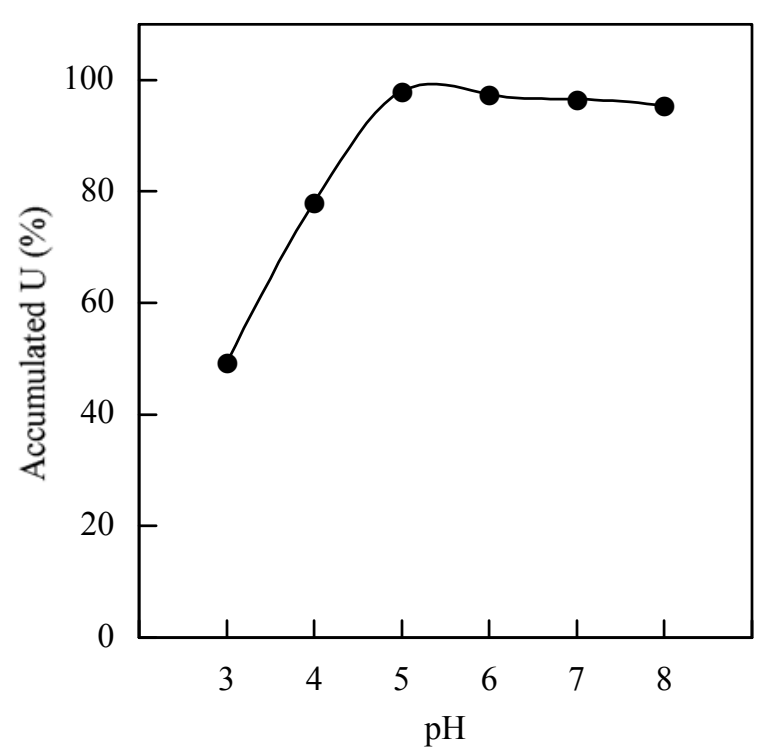

Fig. 2: Effect of $\mathrm{pH}$ on uranium accumulation using Arthrobacter, US-10 cells. Resting cells (15 mg dry wt. basis) were suspended in $100 \mathrm{~mL}$ solution containing $84 \mu \mathrm{M}$ uranium for $1 \mathrm{~h}$ at room temperature

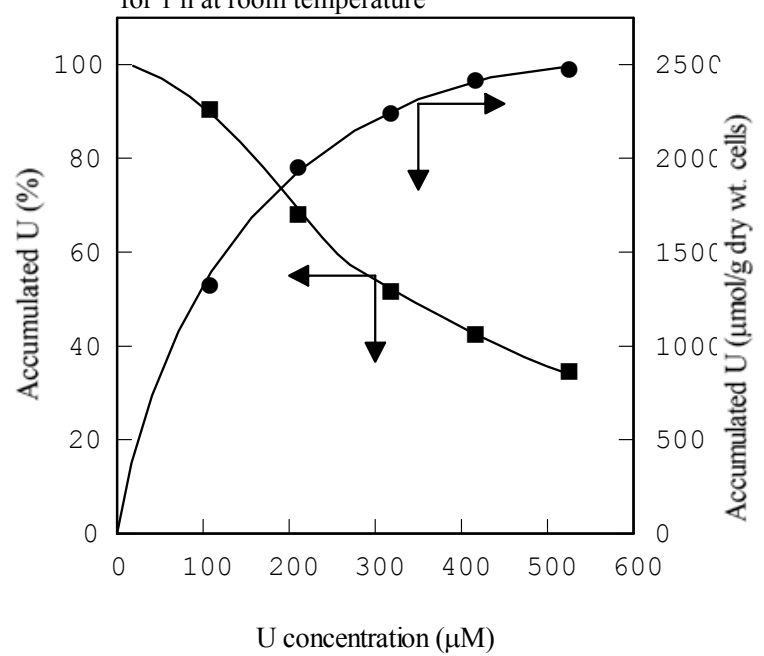

Fig. 3: Effect of external uranium concentration on uranium accumulation using Arthrobacter, US-10 cells. Resting cells (15 mg dry wt. basis) were suspended in $200 \mathrm{~mL}$ solution ( $\mathrm{pH}$ 5.8) containing a desired amount of uranium for $1 \mathrm{~h}$ at room temperature. Symbols: circles, accumulated uranium $(\mu \mathrm{mol} / \mathrm{g}$ dry wt. cells); squares, accumulated uranium $(\%)$

various microorganisms isolated from North American uranium deposits to accumulate uranium, hundreds of strains of microorganisms were screened. As shown a part of the results in Table 1, we have found that the amounts of uranium accumulated by the microbial cells range widely from a minimum value of $14.0 \%$ to a maximum value of $98.3 \%$. Of special interest to this discussion is the wide range effectiveness with which different species of microorganisms accumulate uranium.

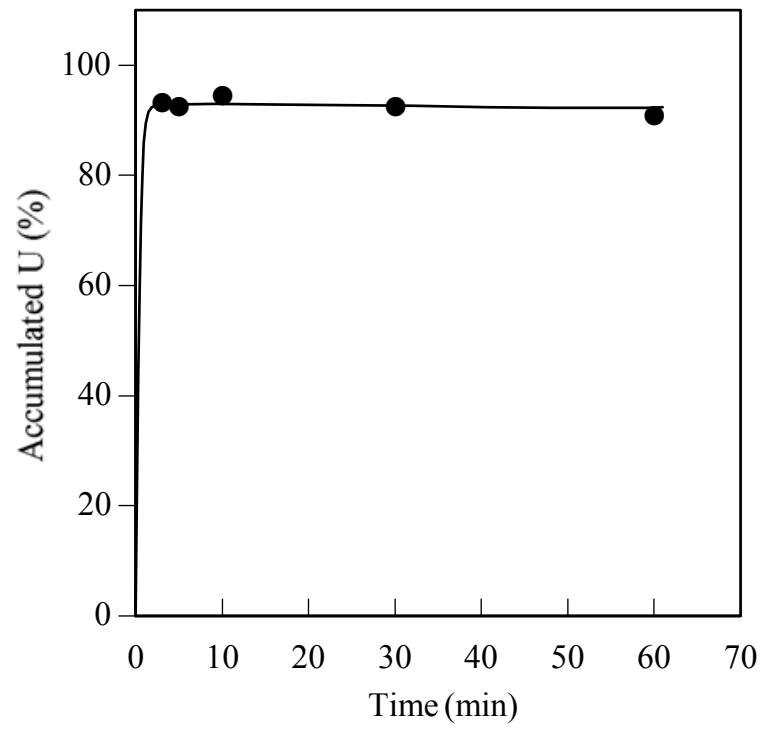

Fig. 4: Time course of uranium accumulation by Arthrobacter, US-10 cells. Resting cells (15 mg dry wt. basis) were suspended in $100 \mathrm{~mL}$ solution ( $\mathrm{pH} 5.8$ ) containing $84 \mu \mathrm{M}$ uranium at room temperature

Of these microorganisms tested, extremely high uranium accumulating ability was found in some strains appeared to be genus bacteria. One of them, Arthrobacter sp., US-10 $0^{[14]}$ found in United States can accumulate the largest amount of uranium per gram of microbial cells within $1 \mathrm{~h}$. In North America, we have also discovered some new strains, such as Bacillus sp., US- $9^{[14]}$ having the high ability to accumulate uranium.

Some factors affecting uranium accumulation using microorganisms: As shown in the above section, some microorganisms isolated from uranium deposits located in North America have an extremely high ability to accumulate uranium. In order to obtain basic information on the removal of uranium using new strains of microorganisms found in uranium deposits, some factors affecting uranium accumulation were investigated in detail using Arthrobacter sp., US-10 isolated from United States uranium deposits.

Effect of pH on the uranium accumulation: The effect of $\mathrm{pH}$ on the uranium accumulation using Arthrobacter sp., US-10 is shown in Fig. 2. The amounts of uranium accumulated are highest at around $\mathrm{pH} 5$ and decrease with increasing acidity below $\mathrm{pH}$ 4. Thus, the accumulation of uranium by Arthrobacter cells is markedly affected by the $\mathrm{pH}$ of the solution. 


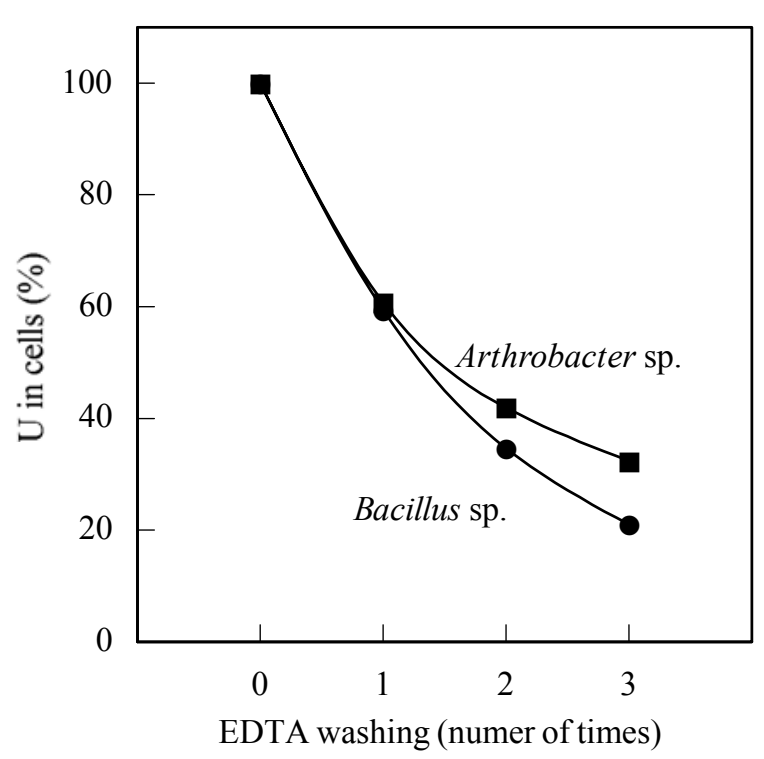

Fig. 5: Release of uranium from Arthrobacter, US-10 or Bacillus, US-9 cells by washing with EDTA solution. Resting cells (15 mg dry wt. basis) were suspended in $100 \mathrm{~mL}$ solution (pH 5.8) containing $84 \mu \mathrm{M}$ uranium for $1 \mathrm{~h}$ at room temperature. Microbial cells with accumulated uranium were washed three times with $10 \mathrm{~mL}$ of $10 \mathrm{mM}$ EDTA solution

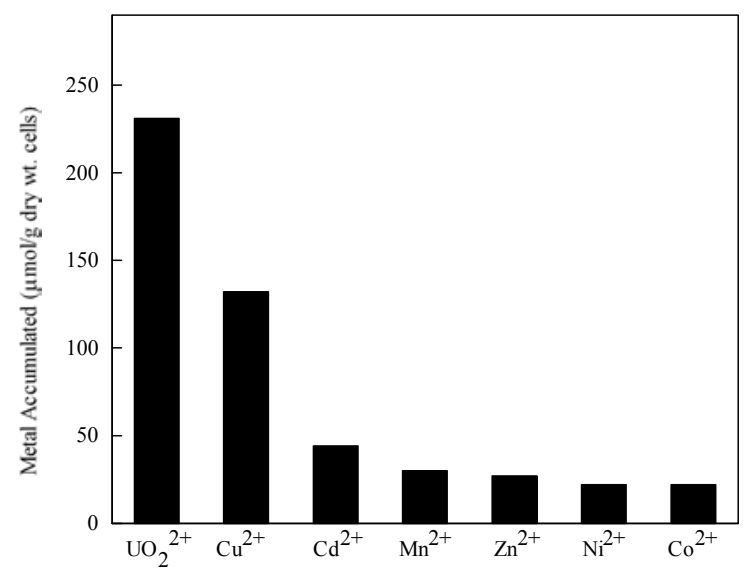

Fig. 6: Selective accumulation of heavy metals using Arthrobacter, US-10 cells. Resting cells (15 mg dry wt. basis) were suspended in $100 \mathrm{~mL}$ of a solution ( $\mathrm{pH} 5.0)$ containing $4 \times$ $10^{-5} \mathrm{M} \mathrm{Mn}^{2+}, \mathrm{Co}^{2+}, \mathrm{Ni}^{2+}, \mathrm{Cu}^{2+}, \mathrm{Zn}^{2+}, \mathrm{Cd}^{2+}$ and $\mathrm{UO}_{2}{ }^{2+}$ for $1 \mathrm{~h}$ at room temperature

Effect of external uranium concentration on the uranium accumulation: It is obvious from Fig. 3 that the amounts of uranium accumulated using Arthrobacter sp., US-10 ( $\mu \mathrm{mol}$ uranium/g microbial cells) increase as the external uranium concentration increases, whereas the ratio of the total amounts of uranium accumulated to the external uranium concentration decreases. When the external uranium concentration is low, the extremely high accumulation ratio is found. It is evident from Fig. 3 that Arthrobacter cells can accumulate $2480 \mu \mathrm{mol}$ uranium per gram of the microbial cells.

\begin{tabular}{lll} 
Table 2: & Distribution of uranium in Arthrobacter sp., US-10 cells \\
\hline Fractions & Accumulated uranium & \\
& -------------------- \\
& $(\mu \mathrm{mol})$ & $(\%)$ \\
\hline Whole cells & 237 & 100 \\
Cell wall fraction & 140 & 59 \\
Intracellular particle fraction & 51 & 21 \\
Intracellular soluble fraction & 32 & 13 \\
\hline
\end{tabular}

Resting cells (640 mg fresh weight) were suspended in $1000 \mathrm{~mL}$ solution ( $\mathrm{pH}$ 5.8) containing $500 \mu \mathrm{M}$ of uranium for $1 \mathrm{~h}$ at room temperature

Time course of the uranium accumulation: It is evident from Fig. 4 that the amounts of uranium accumulated by Arthrobacter sp., US-10 cells increase very rapidly during the first 3 min following the supply of uranium.

Release of uranium from microbial cells by washing with EDTA solution: As shown in Fig. 5, when microbial cells, such as Arhrobacter sp., US-10 and Bacillus sp., US-9 were washed 3 times with $10 \mathrm{mM}$ EDTA solution, about $70 \%(80 \%)$ of the accumulated uranium was desorbed from resting cells in the case of Arhrobacter sp. (Bacillus sp.), suggesting that most uranium in both cells is coupled with ligands that are easily substituted by EDTA. However, 30\% (20\%) of accumulated uranium in Arhrobacter sp. (Bacillus sp.) are not substituted by three times of EDTA washing.

Distribution of uranium in Arthrobacter cells: The present experiments were undertaken to determine which parts of the cells were accumulated uranium in the Arthrobacter, US-10 cells. The Arthrobacter, US-10 cells having accumulated uranium were fractionated as described in Fig. 1.

The amounts in each fraction shown in Table 2 were in the following decreasing order: cell wall fraction $>$ intracellular particle fraction $>$ intracellular soluble fraction. Uranium was found in the cell wall fraction abundantly and small amounts of uranium were in the intracellular fractions.

Selective accumulation of uranium using Arthrobacter., US-10 cells: To determine which heavy metal ions can be most readily accumulated by microbial cells, the selective accumulation of heavy metal ions using Arthrobacter, US-10 cells from a solution containing $4 \times 10^{-5} \mathrm{M}$ of $\mathrm{Mn}^{2+}, \mathrm{Co}^{2+}, \mathrm{Ni}^{2+}, \mathrm{Cu}^{2+}, \mathrm{Zn}^{2+}$, $\mathrm{Cd}^{2+}$ and $\mathrm{UO}_{2}{ }^{2+}$ at $\mathrm{pH} 5$ was examined.

As shown in Fig. 6, the relative degree of magnitude of heavy metal ions accumulated using Arthrobacter, US-10cells appeared to be $\mathrm{UO}_{2}{ }^{2+}>\mathrm{Cu}^{2+}>$ others.

This result shows that Arthrobacter sp., US-10 can readily accumulate uranium compared to other heavy metal ions. 
Table 3: Accumulation of thorium and/or uranium from the solution containing thorioum and/or uranium

\begin{tabular}{|c|c|c|c|c|}
\hline \multirow[t]{2}{*}{ Strain } & \multicolumn{2}{|c|}{$\begin{array}{l}\text { Metal accumulated from the solution containing } \\
\text { Th or } U \text { only }{ }^{\text {a) }}(\mu \mathrm{mol} / \mathrm{g} \text { dry wt.cells })\end{array}$} & \multicolumn{2}{|c|}{$\begin{array}{l}\text { Metals accumulated from the mixed solution } \\
\text { containing Th and } \mathrm{U}^{\mathrm{b})}(\mu \mathrm{mol} / \mathrm{g} \text { dry wt.cells })\end{array}$} \\
\hline & Th & $\mathrm{U}$ & Th & $\mathrm{U}$ \\
\hline Anthorbacter sp. US-10 & 98.8 & 98.9 & 98.5 & 52.1 \\
\hline Bacillus sp. US-9 & 94.0 & 99.7 & 98.3 & 15.8 \\
\hline
\end{tabular}

Accumulation of thorium by microorganisms: As described above, new microorganisms found in American uranium deposits can accumulate uranium with high efficiency. In this course of our study, the question has been raised whether these strains have the accumulating ability for thorium as well as uranium.

The next step in our study was to examine the selective accumulation between uranium and thorium. A comparative study of the selective accumulation between these two metals using microbial cells holds both academic and practical interest because both uranium and thorium are chemically similar nuclear fuels.

As thorium hydroxide is precipitated in a solution containing thorium at $\mathrm{pH} 4.0$, the accumulation of thorium examined at $\mathrm{pH} 3.5$.

It is evident from Table 3 that both Arthrobacter sp., US-10 and Bacillus sp., US-9 can also accumulate thorium with high efficiency. The amount of accumulated uranium from the solution containing both elements at pH3.5 by Arthrobacter sp., US-10 became half of that from the solution containing uranium only, however, that from the solution containing both elements by Bacillus sp., US-9 became far lower than that from the solution containing uranium only. Accordingly, the effect of thorium on uranium accumulation by Bacillus sp., US-9 is stronger than that by Arthrobacter sp., US-10

Recovery of uranium by immobilized microorganisms: As described above, new microorganisms, such as Arthrobacter and Bacillus sp., found in American uranium deposits, can accumulate large amounts of uranium from aqueous systems. However, the free cells of these bacteria are not reusable because of their mechanical instability and susceptibility to cell degradation. Furthermore, free cells are not suitable for use in column systems, because they cause plugging. To overcome these deficiencies in free cells, the cells of Arthrobacter sp., US-10 having a high uranium accumulating ability were immobilized with polyacrylamide.
To obtain basic information on the recovery of uranium using immobilized microbial cells, a repetition test of the uranium adsorption-desorption cycle was carried out. We have previously shown that the uranium retained on the adsorbent can easily be desorbed with dilute $\mathrm{Na}_{2} \mathrm{CO}_{3}$ solution, so we used $0.1 \mathrm{M} \mathrm{Na} \mathrm{CO}_{3}$ solution as the desorbent in this experiment.

As shown in Fig. 7, the ability of the immobilized Arthrobacter cells to adsorb uranium did not decrease after 6 repetitions of the adsorption-desorption cycles in a column system. Thus, immobilized microbial cells have excellent handling characteristics and can be used repeatedly in the adsorption-desorption cycles.

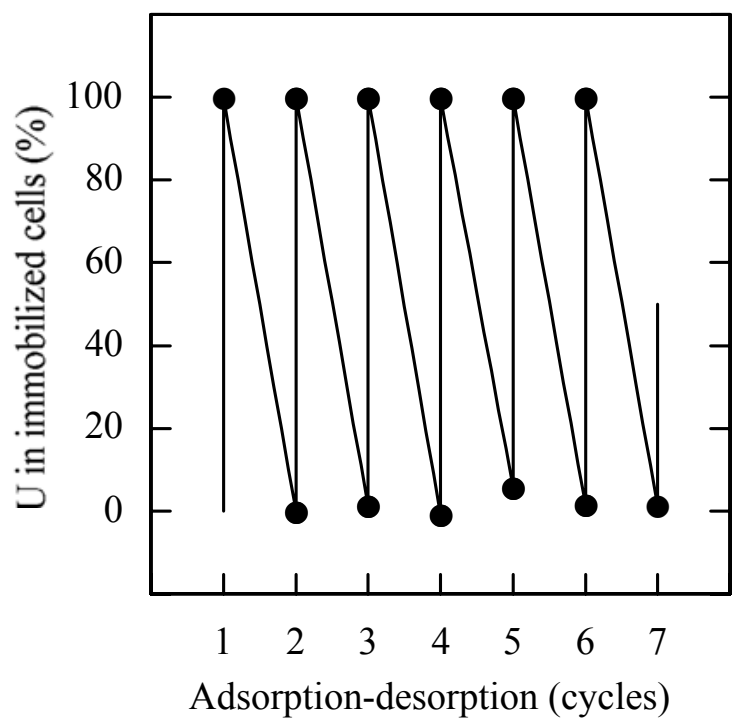

Fig. 7: Test of repeated uranium adsorption-desorption using immobilized Arthrobacter, US-10 cells. Fifteen milliliters of a solution ( $\mathrm{pH} 5.8$ ) containing $42 \mu \mathrm{M}$ uranium was adsorbed on a column (bed volume, $2 \mathrm{~mL}$ ) of immobilized Arthrobacter cells at a space velocity of $20 \mathrm{~h}^{-1}$. Adsorbed uranium was desorbed with $10 \mathrm{~mL}$ of $0.1 \mathrm{M} \mathrm{Na}_{2} \mathrm{CO}_{3}$ solution 
Table 4: Uranium removal from uranium refining wastewater using immobilized microorganisms isolated from uranium mines

\begin{tabular}{ll}
\hline Strains & Accumulated U (\%) \\
\hline Arthrobacter sp., US-10 & 100 \\
Bacillus sp., US-9 & 100
\end{tabular}

Uranium refining waste water $(200 \mathrm{~mL}, \mathrm{pH} 5)$ supplemented with 2.1 $\mathrm{mM}$ of uranium were adsorbed on a column (bed volume $2 \mathrm{~mL}$ ) of immobilized microbial cells at Space velocity of $10 / \mathrm{h}$ at room temperature

Removal of uranium from uranium refining waste water by microorganisms: As mentioned above, some microbial cells have a high uranium accumulating ability, which suggests the possibility that it may be used for removal of uranium from uranium mine tailing, uranium refining waste water and other waste sources.

We have tried to remove uranium from the uranium refining wastewater sampled at the Ningyo-toge Station of the Power Reactor and Nuclear Fuel Development Corporation, using some microorganisms having a high ability to accumulate uranium.

It is evident from Table 4 that these microorganisms can remove uranium from the uranium refining wastewater with high efficiency.

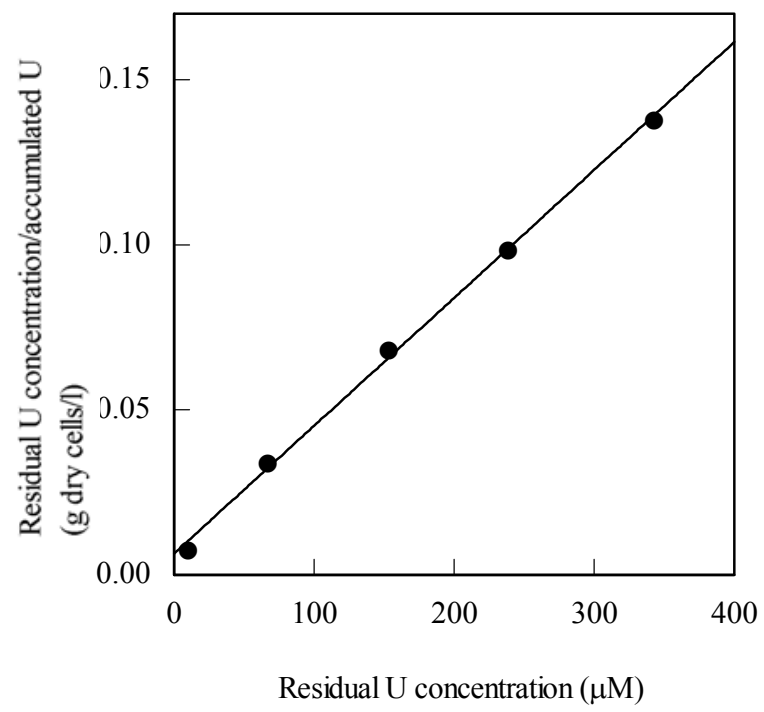

Fig. 8: Equilibrium isotherm of uranium accumulation using Arthrobacter, US-10 cells. Experimental condition was same as Fig. 4

\section{DISCUSSION}

In uranium deposits located in North America, we have discovered some new microorganisms, such as Arthrobacter and Bacillus sp., having an extremely high ability to accumulate uranium.

The amounts of uranium accumulated usinig
Arthrobacter sp., US-10 was affected by the $\mathrm{pH}$ of the solution, however, these strains accumulate can accumulate large amount of uranium at wide $\mathrm{pH}$ 5-8.

The uranium accumulation using Arthrobacter sp., US-10 increases as the external uranium concentration increases. The relationship between the concentration of residual uranium in the solution and the amounts of accumulated uranium calculated from the data of Fig. 3 is shown in Fig. 8. It is obvious from this figure that the accumulation of uranium by the microbial cells obeys the Langmuir isotherm, $\mathrm{C}_{\mathrm{e}} / \mathrm{q}=\mathrm{mC}_{\mathrm{e}}+\mathrm{n}$, where $\mathrm{q}$ indicates the amount of uranium accumulated ( $\mu \mathrm{mol}$ uranium/g dry wt. cells), $\mathrm{C}_{\mathrm{e}}$ is the residual uranium in the solution $(\mu \mathrm{M})$ and $\mathrm{m}\left(=3.88 \times 10^{-4}\right)$ and $\mathrm{n}\left(=6.45 \times 10^{-3}\right)$ are constants. The maximum amount of uranium accumulated ( $\mu \mathrm{mol}$ uranium/g dry wt. cells) is estimated from the slope of the line to be $2580 \mu \mathrm{mol}$ uranium/g dry wt. cells.

As the results of EDTA washing from the Arthrobacter cells, $70 \%$ of accumulated uramium was bound with the surface of cell wall components. The results about distribution of uranium in Arthrobacter cells almost coincided with the results by the EDTA washing.

On the basis of these finding, it seems reasonable to postulate that the accumulated uranium using Arthrobacter sp., US-10 is mostly dependent on physico-chemical binding to the cell components, however, $30 \%$ of that is accumulated in the cytoplasm.

These results contrasted the results of the accumulation patern of uranium in microalge, such as Chlorella regularis, which was accumulated in intracellular soluble fraction $>$ intracellular particle fraction $>$ cell wall fraction ${ }^{[15]}$.

Most of the accumulated uranium was desorbed easily by diluted sodium carbonate solution. In addition, these bacterial cells also have an extremely high affinity for thorium. Accordingly, I consider that these new microorganisms can be used as an adsorbing agent for the removal and recovery of the nuclear fuel elements, which may be present in nuclear fuel processing effluents, mine tailings and other waste sources.

\section{REFERENCES}

1. Andres, Y., H.J. Maccordick and J.C. Hubert, 1993. Adsorption of several actinide (Th, U) and lanthanide ( $\mathrm{La}, \mathrm{Eu}, \mathrm{Yb})$ ions by Mycobacterium smegmatis. Appl. Microbiol. Biotechnol., 39: 413417.

2. Byerley, J.J., J. M.Scharer and A.M. Charles, 1987. Uranium (VI) biosorption from process solutions. Chem. Eng. J., 36: B49-B59. 
3. Friiss, N. and P. Myers-Keith, 1986. Biosorption of uranium and lead by Streptomyces longwoodensis. Biotechnol. Bioeng., 28: 21-28.

4. Gorab, Z., B. Orlowwska and R.W. Smith, 1991. Biosorption of lead and uranium by Streptomyces sp. Water Air Soil Pollut., 60: 99-106.

5. Hu, M.Z. -C., J.M. Norman, B.D. Faison and M.E. Reeves, 1996. Biosorption of uranium by Pseudomonas aeruginosa strain CSU: characterization and comparison studies. Biotechnol. Bioeng., 51: 237-247.

6. Marques, A.M., X. Roca, M.D. Simon-Pujol, M.C. Fusto and F. Congregado, 1991. Uranium accumulation by Pseudomonas sp. EPS-5028. Appl. Microbiol. Biotechnol., 35: 406-410.

7. Strandberg, G.W., S. E.Shumate II and J.R. Parrott, Jr., 1981. Microbial cells as biosorbents for heavy metals: accumulation of uranium by Saccharomyces cerevisiae and Pseudomonas aeruginosa. Appl. Env. Microbiol., 41: 237-245.

8. Galun, M., P. Keller, D. Malki, H. Fedelstein, E. Galun, S. Siegel and B. Siegel, 1983a. Recovery of uranium (VI) from solution using precultured Penicillium biomass. Water Air Soil Pollut., 20: 221-232.

9. Galun, M., P. Keller, D. Malki, H. Feldstein, E. Galun, S. M. Siegel and B.Z. Siegel, 1983b. Removal of uranium (VI) from solution by fungal biomass and fungal wall-related biopolymers. Science, 219: 285-286.

10. Tsezos, M. and B. Volesky, 1981. Biosorption of uranium and thorium. Biotechnol. Bioeng., 23: 583-604.
11. White, C. and G.M. Gadds, 1990. Biosorption of radionuclides by fungal biomass. J. Chem. Technol. Biotechnol. 49: 331-343.

12. Shumate, S.E., II, G.W. Strandberg and J.R. Parrott, Jr. 1978. Biological removal of metal ions from aqueous process streams. Biotechnol. Bioeng. Symp., 8: 13-20.

13. Sakaguchi, T., T. Tsuruta and A. Nakajima, 1996. Removal of uranium by using microorganisms isolated from uranium mines. Proc. Technical Solutions for Pollution Prevention in the Mining and Mineral Processing Industries. Engineering Foundation conference, Palm Coast, FL, USA, pp: 183-191.

14. Sakaguchi, T., 1998. Removal of uranium by using microorganisms isolated from Australian and American uranium deposites. Environment \& Innovation in Mining and Mineral Technology, M. A. Sanchez, F. Vergara and S. H. Castro, Eds, University of Concepcion-Chile, pp: 181-191.

15. Nakajima, A., T. Horikoshi and T. Sakaguchi, 1981. Distribution and chemical state of heavy metal ions absorbed by Chlorella cells., Agric. Biol. Chem., 45: 903-908. 